\title{
Microencapsulation of Crude Folic Acid Extract from Chayote (Sechium Edule Jacq. Swartz) with Ionic Celation Method
}

Johana Novita Paulina Purba ${ }^{1 *}$, Herla Rusmarilin², Zulkifli Lubis ${ }^{3}$

\author{
${ }^{1}$ Department of Food Science, Faculty of Agricultural, Universitas Sumatera Utara, Medan \\ ${ }^{2}$ Department of Food Science, Faculty of Agricultural, Institut Pertanian Bogor, Bogor \\ ${ }^{3}$ Department of Food Science, Universitas of New South Wales, Sydney, Australia \\ * Corresponding author, email address: johanapaulina0@gmail.com
}

\begin{abstract}
Chayote is a plant which grows and develops throughout the year, contains of $93 \mu \mathrm{g} / 100 \mathrm{~g}$ folic acid. The aim of this research was to determine the ratio of sodium alginate with pectin and $\mathrm{CaCl}_{2}$ concentration coating to produce microcapsules of crude folic acid extract. Three steps of experiments were carried out; ie. Folic acid extraction, microencapsulation of folic acid with ionic gelation, and the analysis of folic acid content and stability during storage. The folic acid extract was obtained by maceration using alcohol $70 \%$ at $\mathrm{pH}$ 6, preparation of the microcapsules was obtained sodium alginate with pectin and folic acid was analyzed using HPLC. Folic acid extract showed antioxidant activity of $98.1 \%$ with folic acid of $0.16 \mathrm{mg} / \mathrm{kg}$. Microencapsulation of folic acid extract results showed the highest antioxidant activity was formed in alginate ratio of $70 \%$ to $30 \%$ pectin and $\mathrm{CaCl}_{2}$ concentration of $0.1 \mathrm{M}$ i.e. $62.77 \mathrm{mg} / \mathrm{kg}$. Folic acid is an antioxidant, highest antioxidant value folic acid was analyzed, treatment was in alginate ratio of $70 \%$ to $30 \%$ pectin and $\mathrm{CaCl}_{2}$ concentration at $0.1 \mathrm{M}$ i.e. $3.06 \mathrm{mg} / \mathrm{kg}$, after one week at room temperature becomes $2.39 \mathrm{mg} / \mathrm{kg}$.
\end{abstract}

Keywords: folic acid; chayote; microencapsulation; sodium alginate; pectin.

\section{INTRODUCTION}

Deficiency of folic acid causes the body susceptible to diseases such as depression, anxiety, fatigue, insomnia, the difficulty of remembering, red tongue and wounds to indigestion. In pregnant women a deficiency of folic acid increases the risk of premature delivery, low birth weight infants or neural tube defects (Bender, 2002). Therefore, sufficient intake of folic acid is crucial especially for pregnant woman. However, folic acid is highly unstable, water-soluble, and easily damaged by heat (Yuniati and Almasyhuri, 2012), therefore special treatment is required to stabilize folic acid.

Chayote is one of natural resources that potential to be the source of folic acid. It contains a high enough folic acid at $93 \mathrm{mcg} / 100 \mathrm{~g}$ (USDA, 2008) with the huge production in North Sumatra up to 20,306 tons/year in 2014 (Statistic Indonesia, 2014).

Encapsulation techniques is usually used to protect a functional substances such as folic acid. Sodium alginate and pectin are usually used as a coating agent to protect the core material through ionic gelation method (Syahron, 2016). Polyelectrolyte solutions are formed between the polyions with opposite charges, the electrostatic interaction between the charged polyions (Lankapalli and Kolapalli, 2009). Sodium alginate and pectin dispersed into the aquades are a solution of polyelectrolytes, and ions that derived from $\mathrm{CaCl} 2$ are utilized to form crosslinks. Therefore, the core material of folic acid extracted from the gourd possibly can be maintained its stability with microencapsulation using sodium alginate polymer and pectin.

To the best of our knowledge, there are limited scientific publication study the microencapsulation of folic acid from Chayote. In this research, experiments were focused on the determination of ratio sodium alginate and pectine for folid acid microencapsulation, to determine the best concentration of $\mathrm{CaCl}_{2}$ which yields the best folic acid extract microcapsules from the crude folic acid extract microcapsules, and to determine the best folic acid content of microcapsules based on the best antioxidant activity.

\section{MATERIALS AND METHODS \\ Materials}

Materials used are chayote (Sechium edule Jacq. Swartz) obtained from Berastagi Supermarket, Medan. Chemicals used in this study was $70 \%$ alcohol, alginate, pectin, and $\mathrm{NaOH} 10 \mathrm{~N}$.

\section{Methods}

Preparation of Folic Acid Extract

Chayote was washed, cleaned and sliced ditrimming formed slash, then squash dried in an oven at a temperature of $45^{\circ} \mathrm{C}$. Chayote dried pulverized and sieved with a sieve of 60 mesh (Rahmadhayanti, 2013).

$1 \mathrm{~kg}$ of Chayote powder were extracted using $1.7 \mathrm{~L} 70 \%$ ethanol at $\mathrm{pH}$ of 6 in the absence of light using maceration techniques performed by Greene (2016). The crude folic acid extract were then concentrated using rotary evaporator at $40{ }^{\circ} \mathrm{C}, 60 \mathrm{rpm}$ and $200 \mathrm{mBar}$.

Preparation of microcapsules by ionic gelation method (Vajpayee et al., 2011 with modification by Syahron, 2016; Chakraverty 2012 with modification by Oktaviana, 2015).

$2 \mathrm{~g}$ of sodium alginate-pectin mixture with ratio of $65 \%$ : 35\%, 70\%: 30\%, 75\%: $25 \%$ was brought into the mortal which was then added with iadest. The mixture was then 
added into $100 \mathrm{ml}$ of water, dropwise, accompanied by stirring at $300 \mathrm{rpm}$ for 30 minutes untill a mucilago was obtained. Subsequently, $10 \mathrm{ml}$ of folic acid extract was added into the solution. The folic acid microparticles of the squash are formed by dripping the mucilago dispersions of alginate-pectin alpha-folic acid extract using $21 \mathrm{G}$ syringe dripped into $30 \mathrm{~mL}$ of $\mathrm{CaCl}_{2}$ solution for 30 minutes (Figure 1). The microparticles formed are then filtered and washed using aquadest. The formed microparticles are dried in the oven at $37^{\circ} \mathrm{C}$ for 10 hours.

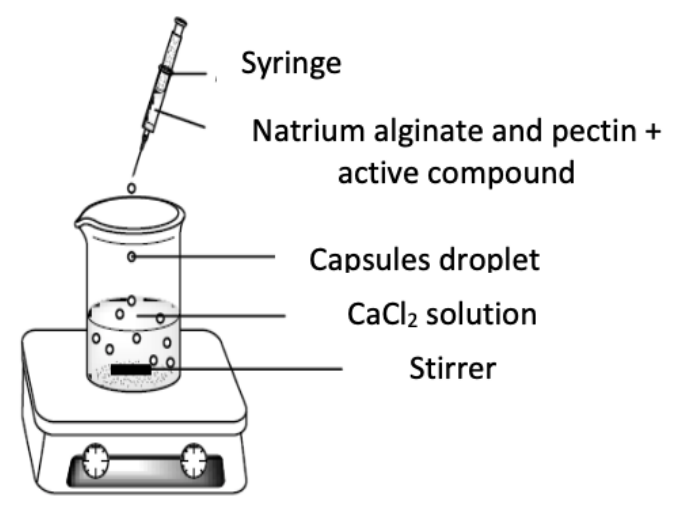

Figure 1. Illustration of the experimental set up

\section{Analysis of Folic Acid Content in microcapsules (Arcot} \& Shrestha, 2005).

a. Preparation of Standard Solution

The standard folic acid was prepared by dissolving in 0.1 $\mathrm{M}$ buffer dibasic potassium phosphate $(\mathrm{pH}$ 8-8.5) which contained $0.1 \%$ ascorbic acid and $0.1 \%$ 2-mercaptoetanol so that the concentration of folic acid to $200 \mathrm{mg} / \mathrm{mL}$. Standard solution should be used as soon as possible to avoid damage of folic acid.

\section{b. Enzyme}

A-amylase enzyme (EC 3.2.1.1) produced by Aspergillus oryzae was used in this study. Enzim dissolved in distilled water so that its concentration was $25 \mathrm{mg} / \mathrm{mL}$. $1 \mathrm{~mL}$ of enzyme was used for 1 gram of sample. The enzyme was then further diluted to have concentration of $5 \mathrm{mg} / \mathrm{mL}$.

\section{c. Sample}

$5 \mathrm{~g}$ crude extract were added with $50 \mathrm{~mL}$ solution $(0.1$ $\mathrm{M}$ dibasic potassium phosphate ( $\mathrm{pH} 8-8.5)$, ascorbic acid $0.1 \%$ and $0.1 \%$ 2-mercaptoetanol) and homogenized for an hour. The sample was then heated using autoclave for 15 minutes, cooled in ice bath, and homogenized. It was then incubated with $1.25 \mathrm{ml} \alpha$-amylase (EC 3.2.1.1) at $37^{\circ} \mathrm{C}$ for 4 hours. Subsequently, the sample was added with 1 $\mathrm{mL}$ of protease for 1 hour at $37^{\circ} \mathrm{C}$ and then heated for 5 minutes in boiling water. After incubation, the sample was centrifuged for 20 minutes at $4000 \mathrm{rpm}$. The supernatant was filtered with whatman 42 , then stored in temperature $\left(-20^{\circ} \mathrm{C}\right)$ or injected immediately.

The analysis of folic acid was performed using Reverse Phase-HPLC eqipped with UV/Vis detector with the flow set at $1 \mathrm{~mL} / \mathrm{min}$ and wavelength at $280 \mathrm{~nm}$. two types of mobile phase namely, solution A, $28 \mathrm{mmol} / \mathrm{L}$ dibasic potassium phosphate and $60 \mathrm{mmol} / \mathrm{L}$ potassium acid in water, and solution $\mathrm{B}, 28 \mathrm{mmol} / \mathrm{L}$ dibasic potassium phosphate and $60 \mathrm{mmol} / \mathrm{L}$ of phosphoric acid in 200 $\mathrm{mL} / \mathrm{L}$ acetronitrile and $800 \mathrm{~mL} / \mathrm{L}$ water were used. In the first 3 minutes, $100 \%$ of solution $\mathrm{A}$ is used. In the next 10 minutes, the composition of the mobile phase was changed into $70 \%$ of Solution A and $30 \%$ of solution B. The eluent composition was again changed to $45 \%$ solution A and $55 \%$ solution B for 27 minutes. In the last 15 minutes, the mobile phase composition was changed to $43 \%$ of solution A and $57 \%$ of solution $B$.

Stability testing of folic acid extract microcapsules after storage for one week (Onayanti, 2015).

The stability test of the encapsulated folic acid extract was performed for 1 week at temperature of $28^{\circ} \mathrm{C}$.

\section{Observation and Data Analysis}

\section{Crude Fiber Content (Sudarmadji et al., 1989)}

$2 \mathrm{~g}$ of sample (dry matter) were transferred into a $500 \mathrm{ml}$ erlenmeyer. $200 \mathrm{ml}$ of $\mathrm{H}_{2} \mathrm{SO}_{4}$ was then added into solution followed by covering the solution and boiling for 30 minutes, shaking occasionally. The suspension is filtered through a filter paper and the residue left in the filter paper was washed with boiling aquadest until the washed water was not acidic anymore.

Subsequently, the residue was transfered into an Erlenmeyer by washing it with $200 \mathrm{ml}$ of $0.313 \mathrm{NaOH}$ solution. The solution was then boiled followed by cooling and shaken occasionally for 30 minutes. Afterwards, the solution was filtered using a filter of a known weight and washed with $10 \%$ of $\mathrm{K}_{2} \mathrm{SO}_{4}$ solution. Lastly, the residue was washed with boiling aquadest followed by $15 \mathrm{ml}$ of $95 \%$ alcohol. The filter paper was then dried at $105^{\circ} \mathrm{C}$ for $1-2$ hours. The fiber content can then be calculated using the following equation:

Crude fiber $(\%)=$

$$
F_{0}=\frac{F_{2}+F_{1}}{F_{i}} \times 100 \%
$$

(Eq. 1)

$$
\begin{aligned}
& \text { where: } \\
& \begin{array}{ll}
F_{0} \quad=\text { Crude fiber }(\%) \\
F_{1} \quad=\text { Filter paper weight }(\mathrm{g}) \\
F_{2} \quad=\text { Total weight of filter paper and fiber (B) } \\
F_{1} \quad=\text { Initial sample weight }(\mathrm{g})
\end{array}
\end{aligned}
$$

\section{Water Content (AOAC, 1995)}

$5 \mathrm{~g}$ of sample was put into an aluminum cup of known weight which had been dried for one hour at $105^{\circ} \mathrm{C}$. The sample was dried at $105^{\circ} \mathrm{C}$ for three hours, cooled in a desiccator, and weighted. These steps were repeated until a constant sample weight was obtained. The water content was then calculated by the formula: 
Water Content $(\%)=$

$$
\begin{aligned}
& \qquad W_{w}=\frac{W_{i}-W_{f}}{W_{i}} \times 100 \% \\
& \text { where: } \\
& W_{\mathrm{w}}=\text { Water content }(\%) \\
& W_{1}=\text { Initial weight }(\mathrm{g}) \\
& \mathrm{W}_{\mathrm{f}}=\text { End weight }(\mathrm{g})
\end{aligned}
$$

(Eq. 2)

\section{Acidity Level (pH) (AOAC, 1970)}

Prior to $\mathrm{pH}$ measurement, the samples were diluted with a dilution factor of 4 times. The $\mathrm{pH}$ of the solutions were measured using $\mathrm{pH}$ meter.

\section{Total Soluble Solid (TSS) (Muchtadi and Sugiono, 1990)}

The total soluble solid was measured using handrefractometer. Briefly, $5 \mathrm{~g}$ of sample was brought into a beaker glass and aquadest was added to obtain solution with a total weight of $15 \mathrm{~g}$. The mixture was then stirred to obtain a homogenous solution. One drop of the solution was required for the measurement. The TTS was calculated using the following equation:

Total Soluble Solid $\left({ }^{\circ}\right.$ Brix $)=$

$$
T S S=H R \times F P
$$

(Eq. 3)

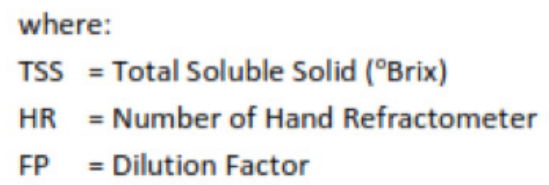

5. Microcapsule Morphology and Structure (HiroxUSA, 2008)

The surface morphology and structure of microcapsules were observed using the Hirox Audio Video Microscope at 60 X magnification with MX (G) - 2016 lens and camera at level of 128, equipped with a standard gamma. The intensity of the LED light source was set at $5700 \mathrm{~K}$ with the color of the light $(5460 \mathrm{~K})$ produces sample color images and fast lighting right in the absence of heating time.

\section{Antioxidant activity (Departemen Kesehatan} Republik Indonesia, 1979; Swastika et al., 2013)

a. Preparation of methanol extract

$10 \mathrm{~g}$ of sample was added into $90 \mathrm{ml}$ of methanol. The sample should be fully submerged. The container was closed tightly and mixture was left undisturbed for 5 days in a dark place. Afterwards, the solution was filtered and moved to another container. The process was repeated until the sample is perfectly filtered. The liquid extract obtained was then evaporated for 15 minutes at $70^{\circ} \mathrm{C}$ and atmospheric pressure in a water.

\section{b. Preparation of DPPH solution}

$50 \mathrm{mg}$ of crystal DPPH was mixed with ethanol in $100 \mathrm{ml}$ poultice flask to obtain DPPH concentration of $0.05 \%$. This stock solution was then diluted to concentration of $0.004 \%$.

c. Measuring the antioxidant activity by immersion method DPPH

$1.0 \mathrm{ml}$ of $0.004 \%$ DPPH solution was mixed with certain amount of absolute ethanol to obtain solution with a total volume of $50 \mathrm{ml}$. The absorbance of the solution was measured using spectrophotometer at $\lambda 518 \mathrm{~nm}$, with pure ethanol as a blank. For antioxidant activity analysis of the sample: $2 \mathrm{ml}$ of sample solution was taken and incorporated into a $50 \mathrm{ml}$ Erlenmeyer which was then added with $1 \mathrm{ml}$ of DPPH solution and $4 \mathrm{ml}$ of ethanol. The mixture was then left undisturbed and protected from light. Subsequently, the mixture was vortexed for 20 second and the absorbace was read in a spectrophotometer. The amount of antioxidant activity was then calculated using the following formula:

Antioxidant activity $(\%)=$

$$
A A=\frac{A_{c}-A_{s}}{A_{c}} \times 100 \%
$$

$$
\begin{aligned}
& \text { where: } \\
& \begin{array}{l}
A A=\text { Antioxidant activity } \\
A_{c}=\text { Control absorption } \\
A_{s} \quad=\text { Sample absorption }
\end{array}
\end{aligned}
$$

\section{RESULT AND DISCUSSION}

Antioxidant activity of non-microencapsulated folic acid extract was $98.1 \%$ with folic acid content of $0.82 \mathrm{mg} / \mathrm{kg}$, the yield was then microencapsulated into microcapsules of crude folic extract. The highest antioxidant activity (\%) was observed in the folat acid treated with $\mathrm{A}_{2} \mathrm{M}_{2}$ treatment which contained sodium alginate and pectin with ratio of $70 \%: 30 \%$ and $0.1 \mathrm{M} \mathrm{CaCl}_{2}$ with folic acid concentration of $3.06 \mathrm{mg} / \mathrm{kg}$. The content of folic acid decreased significantly from $3.06 \mathrm{mg} / \mathrm{kg}$ to $2.39 \mathrm{mg} / \mathrm{kg}$ after one week.

\section{Crude Fiber Content}

The results of variance analysis showed no significant effect on the coarse fiber content of crude folic acid extract microcapsules. The ratio of sodium alginate to pectin and the concentration of $\mathrm{CaCl}_{2}$ significantly influence the crude fiber content of the microcapsules. The effect of sodium alginate ratio to pectin and $\mathrm{CaCl}_{2}$ on crude fiber content of folic acid extract microcapsules can be seen in Figure 2 and Figure 3, respectively.

It can be seen (Figure 2) that the higher the sodium alginate or the lower the pectin, the higher was the crude fiber content

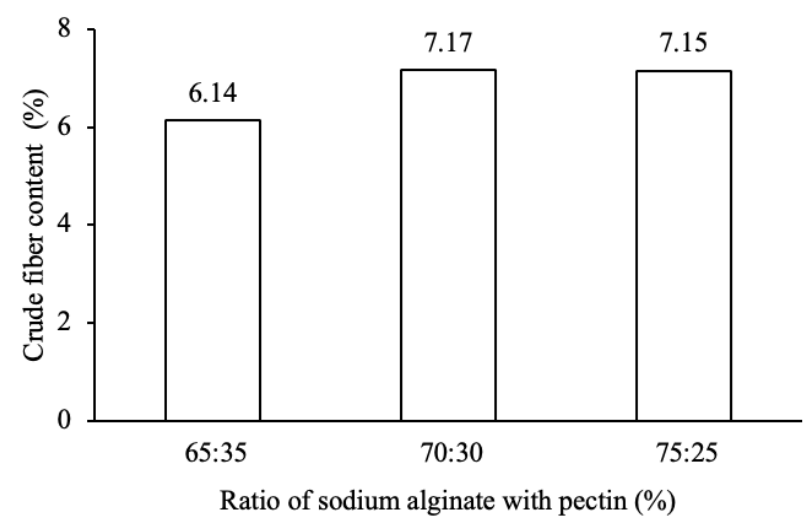

Figure 2. Effect of sodium alginate and pectin ratio on the crude fiber content of crude folic acid extract microcapsules 
of the microcapsules. This can be explained by the fact that the alginate which is obtained from seaweed (Aslan, 1999) is richer in fiber than pectin. According to Dwiyitno (2011), the total fiber content in seaweed is relatively higher than that of food stuffs derived from land plants (tubers, fruits, cereals, and nuts). Besides, terrestrial plant fibers typically contain more water insoluble fiber than seaweed. Pectin is a soluble fiber found in fruits, glucan on cereals, and gums in nuts, seeds, and seaweed (Enema, 1976).

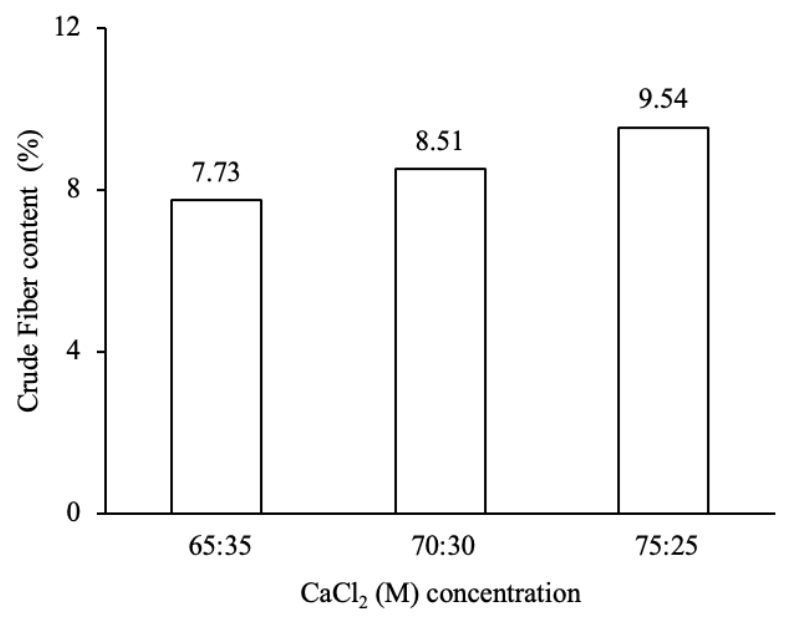

Figure 3. The effect of $\mathrm{CaCl}_{2}$ concentration on the crude fiber content of crude folic acid extract microcapsules

It can be seen (Figure 3 ) the calcium alginate fiber and pectin tended to bind calcium and formed a solid microcapsules. Calcium bonded by alginates will determine how many bonds occur to form fibers. The higher fiber content observed at higher $\mathrm{CaCl}_{2}$ concentration in this research was assumed to be originated purely from the high alginate concentration used (Peranginangin et al., 2015).

\section{Water Content}

There was no significant effect of sodium alginate-pectin ratio and $\mathrm{CaCl} 2$ concentration interaction on the water content of the microcapsules extract folic acid, but each treatment factor provides highly significant effect on the water content. The effect of sodium alginate-pectin ratio and $\mathrm{CaCl}_{2}$ concentration on water content can be seen in Figure 4 and Figure 5, respectively.

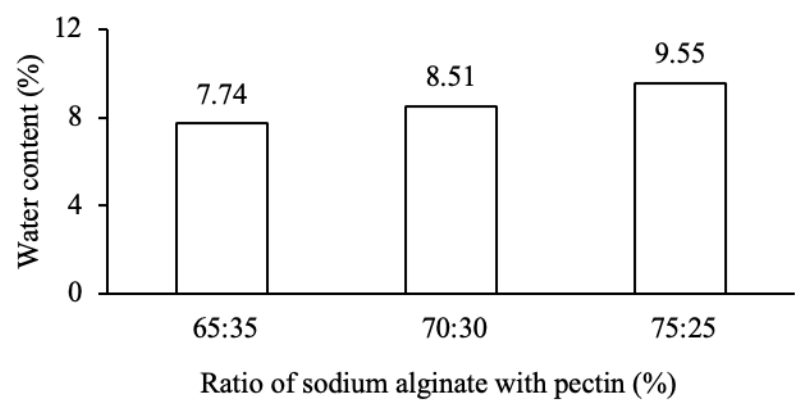

Figure 4. Effect of sodium alginate and pectin ratio on water content of crude folic acid extract microcapsules

It can be seen (Figure 4) that the higher the sodium alginate or the lower the pectin, the higher was the water content because pectin is a very strong water binder. According to
Estiasih and Ahmadi (2009), pectin added to the foodstuff can solidify a homogeneous dispersion system, increase the viscosity of the material, and reduce the water content of the material. The increase in the amount of pectin can decrease the levels of water in the materials produced (Juwita et al., 2014). This could be also due to the ability of Sodium Alginate to bind high amount of water. According to Dwijayanti (2009), sodium alginate is soluble in water

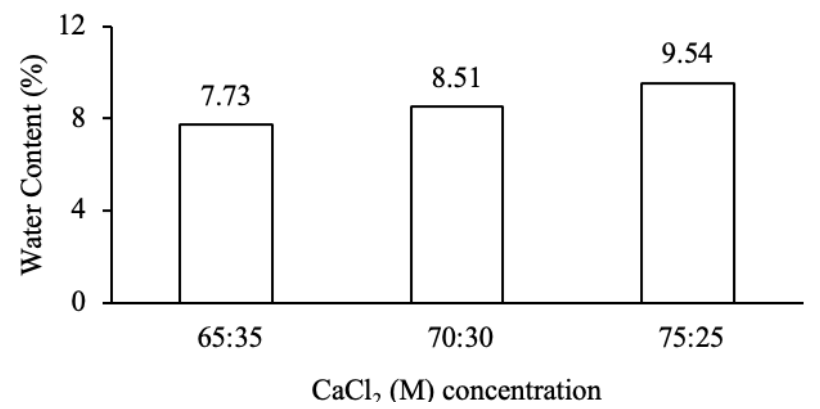

Figure 5. The effect of $\mathrm{CaCl} 2$ concentration on water content of crude folic acid extract microcapsules

and that the fiber material forms a mesh-like grid that is able to bind strongly to a lot of water molecules and retain water solutes well.

Low water content is good for the storage of the microcapsules since it leads to longer shelf life because water can be a medium for microbial growth such as fungi. Microorganisms can grow well at moisture content above 10\% (Faradiba et al., 2013).

\section{Acidity Level (pH)}

The interaction between the ratio of sodium alginate to pectin and concentration of $\mathrm{CaCl}_{2}$, showed highly significant effect on the level of acidity $(\mathrm{pH})$ of folic acid extract microcapsules. The effect of ratio of Sodium alginate to pectin pectin and $\mathrm{CaCl}_{2}$ on acidity level $(\mathrm{pH})$ of crude folic acid extract microcapsules is shown in Figure 6.

According to Madziva et al. (2006), the hydrogel alginatepectin showed remarkable stability in acidic conditions and that hydrogel bond would be released in alkaline conditions. Folate is susceptible to oxidative degradation induced by oxygen, light, sunlight, oxidation and reduction, and heat, which cause the molecules to become biologically active. Folic acid stability also depends on the $\mathrm{pH}$. Whereas the reduced folate binding hydrogels are most vulnerable at $\mathrm{pH}>8$ and $\mathrm{pH}<2$, they are stable in the $\mathrm{pH}$ range of 4-6. Food with high level of acidity (low $\mathrm{pH})$ is most likely to be stable againts microbial growth (Winarno, 2008).

\section{Total Soluble Solid (TSS)}

The interaction of sodium alginate to pectin ratio and $\mathrm{CaCl}_{2}$ concentration had significant effect on the total soluble solid (TSS) of crude folic acid extract microcapsules.

The higher the sodium alginate or the less pectin, the higher was the total soluble solid (TSS) as Sodium alginate increased the total sugar. According to Dwijayanti (2009), the addition of sodium alginate can increase the total sugar 


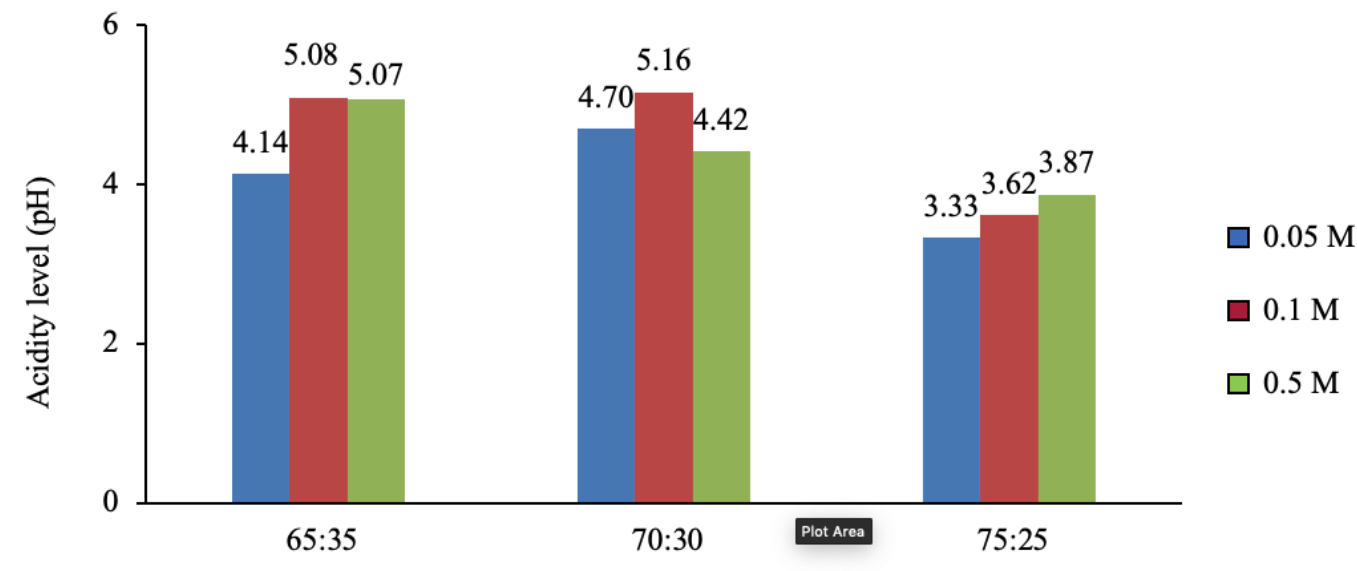

Ratio of sodium alginate with pectin (\%)

Figure 6. The effect of sodium alginate to pectin ratio and $\mathrm{CaCl}_{2}$ concentration on acidity level $(\mathrm{pH})$ of crude folic acid extract microcapsules

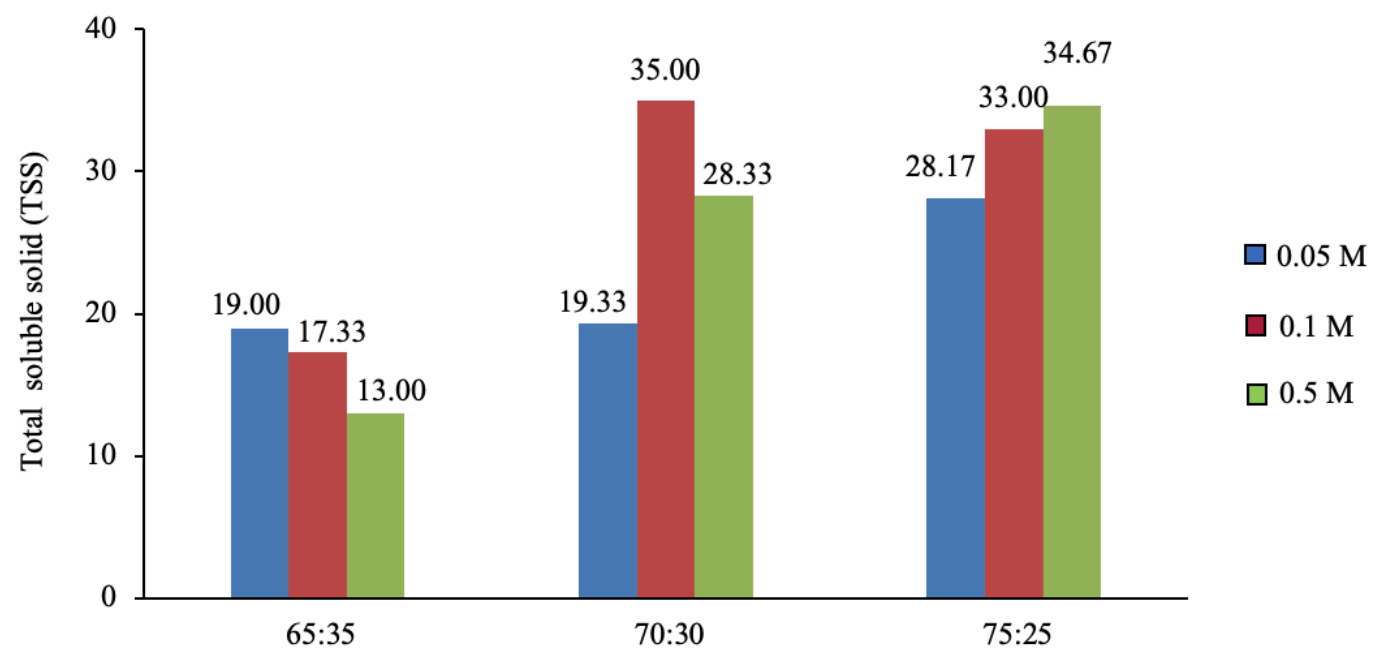

Ratio of sodium alginate with pectin (\%)

Figure 7. The effect of sodium alginate to pectin ratio and $\mathrm{CaCl}_{2}$ concentration on total soluble solid (TSS) of crude folic acid extract microcapsules

in the ingredients. Alginate is a hydrocolloid compound composed of polysaccharides, in which the polysaccharides are sugar polymers with long chain (Fardiaz, 1989).

Total soluble solid (TSS) decreased with increased concentrations of $\mathrm{CaCl}_{2}$. According to Abror and Cahyaningrum (2015), this was due to the bond formed at high concentration of $\mathrm{CaCl}_{2}$.

The high content of crude folic acid extract microcapsules was due to the ability of $70 \%$ alcohol to extract the flavonoids which contain hydroxyl groups (sugar) better than other solvents. According to Marliana (2005), the ethanol extract of chayote (Sechium edule jacq. Swartz) contains flavonoid compounds and according to Melodita (2011), flavonoid is a compound of phytochemical class that is polar as it has a hydroxyl group (sugar) that dissolves in polar solvents such as ethanol, methanol, acetone, water, and others. Sani et al. (2014) stated that $70 \%$ ethanol extract contains flavonoid glycosides, most flavonoid compounds in plants are found in the form of glycosides which means that the flavonoid unit tends to be attached to a carbonyl group of sugars (glycine). Anggraini (2006) stated that all compounds were able to be well extracted in $70 \%$ alcohol because it is semi polar and thus all active components with different polarity can be extracted. In addition, Harbone (1988) stated that $70 \%$ alcohol can better extract the flavonoids than other solvents.

\section{Microcapsule Form}

The best form of microparticles was obtained from alginate-pectin ratio of $75 \%: 25 \%$ and $\mathrm{CaCl}_{2}$ concentration of $0.5 \mathrm{M}$ which produced spere microparticles. On the other hand, alginate-pectin ratio of $65 \%: 35 \%$ and $\mathrm{CaCl}_{2}$ concentration of $0.05 \mathrm{M}$ produced irregular sphere. It seems that the higher the concentration of alginate, the bigger was the microcapsule. According to Tello et al. (2015), alginate increases size, whereas pectin shrinks the size of microparticles. In addition, according to Syahron (2016), capsules which are produced with less concentration of pectin have a shape which is close to spherical. 
Microencapsulated forms can be seen in Figure 8.

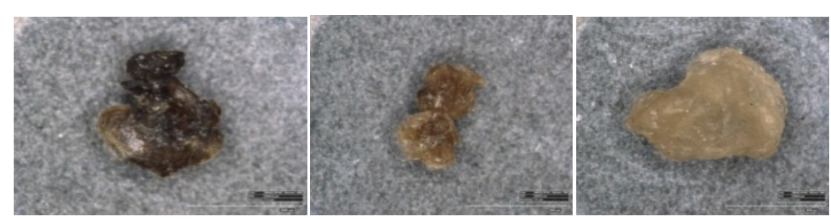

$A_{1} M_{1}(60 \%: 35 \% ; 0.05 M) \quad A_{1} M_{2}(60 \%: 35 \% ; 0.1 M) A_{1} M_{3}(60 \%: 35 \% ; 0.5 M)$

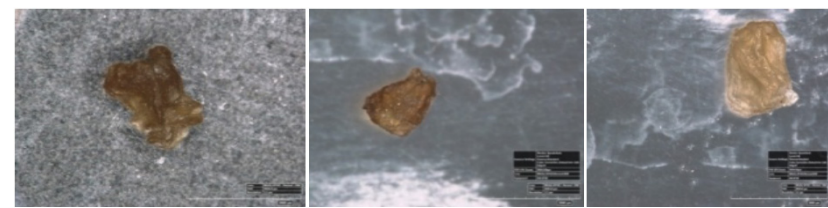

$\mathrm{A}_{2} \mathrm{M}_{1}(70 \%: 30 \% ; 0.05 \mathrm{M}) \quad \mathrm{A}_{2} \mathrm{M}_{2}(70 \%: 30 \% ; 0.1 \mathrm{M}) \quad \mathrm{A}_{2} \mathrm{M}_{3}(70 \%: 30 \% ; 0.5 \mathrm{M})$

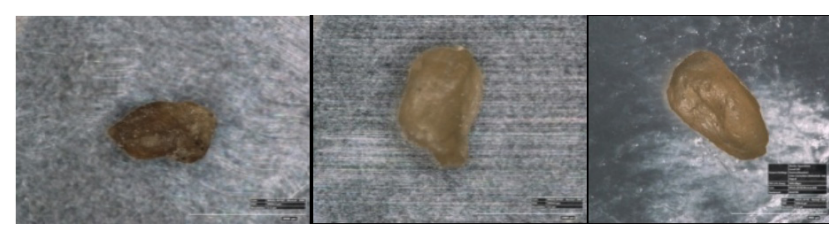

$\mathrm{A}_{3} \mathrm{M}_{1}(72 \%: 25 \% ; 0.05 \mathrm{M}) \quad \mathrm{A}_{3} \mathrm{M}_{2}(75 \%: 25 \% ; 0.1 \mathrm{M}) \quad \mathrm{A}_{3} \mathrm{M}_{3}(75 \%: 25 \% ; 0.5 \mathrm{M})$

Figure 8. Microencapsulated forms of crude folic acid extract

Microencapsulated crude folic acid extract formed an uneven shape (inclined round). Accoring to Oktaviana (2015), the tip of a tapered microcapsule is due to uses a syringe with a pointed needle tip. The microcapsule surface obtained from this research was also uneven and potholes. According to Febriyenti et al. (2013), the uneven surface is generated due to a non-homogeneous solution, thus air bubbles are trapped inside.

Wet microcapsules are spreaded, and after drying they became unstable. According to Sari et al. (2012), due to the heat transfer process during drying, the water absorbed in the wet microcapsule is pushed out so that the microcapsule structure is not stiff. Wet microcapsules and dry microcapsules of crude folic acid extract can be seen in Figure 9.

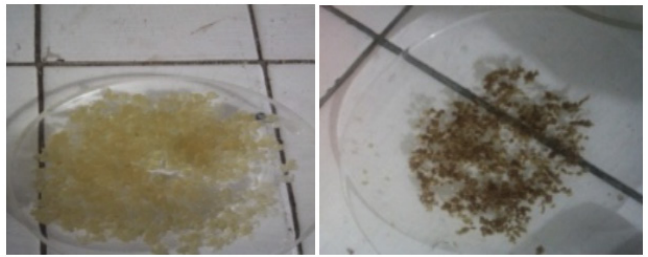

Figure 9. Wet microcapsules and dry microcapsules of crude folic acid extract

\section{Diameter ( $\mu m)$}

The interaction between the ratio of sodium alginate to pectin and $\mathrm{CaCl}_{2}$ concentration showed highly significant effect on the diameter of crude folic acid extract microcapsules. Microcapsules of crude folic acid extract prepared with sodium alginate-pectin ratio of $72 \%: 25 \%$ and $\mathrm{CaCl}_{2}$ concentration of $0.1 \mathrm{M}$ had the highest antioxidant activity $62.77 \%$ as can be seen in Figure 10.

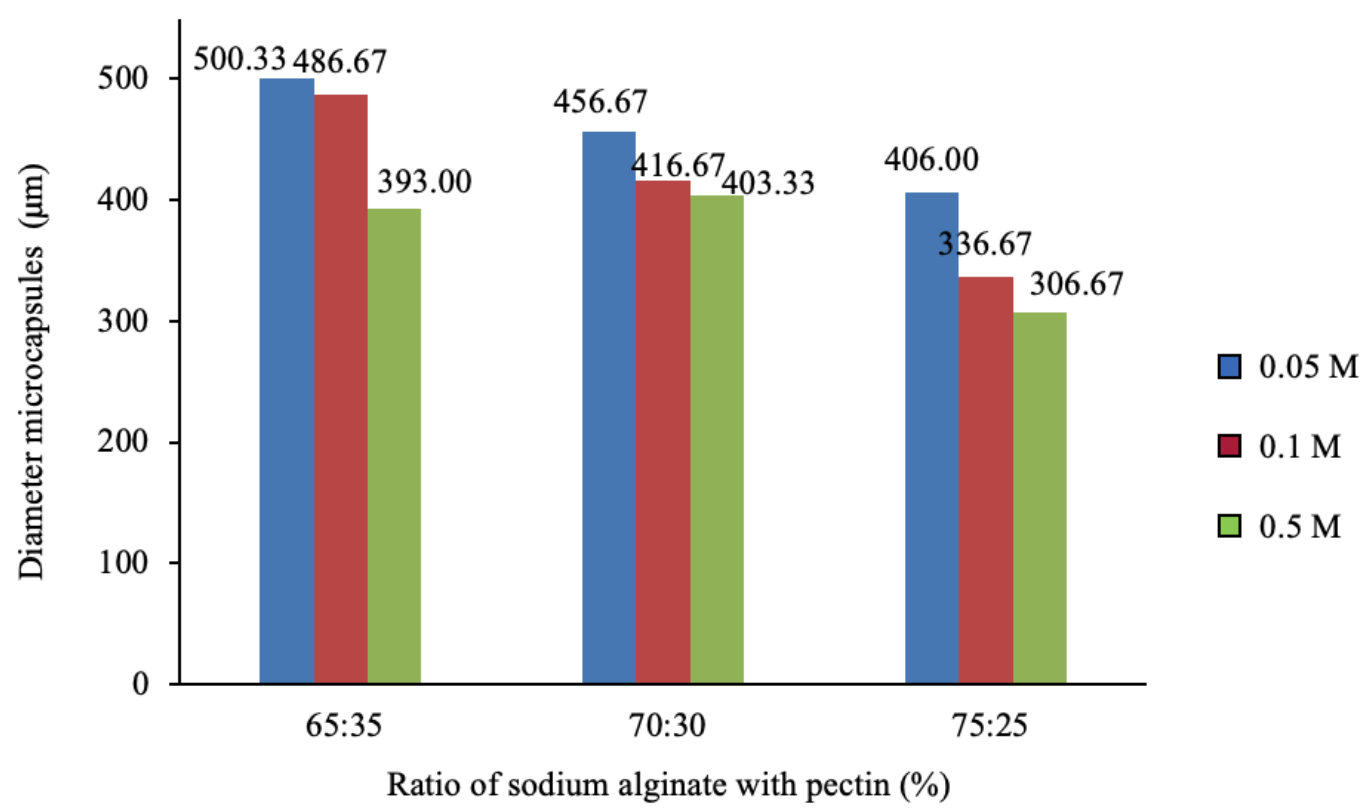

Figure 10. The effect of sodium alginate-pectin ratio and $\mathrm{CaCl}_{2}$ concentration on diameter $(\mu \mathrm{m})$ of crude folic acid extract microcapsules

The increasing concentration of $\mathrm{CaCl}_{2}$ resulted in a harder, stiffer, and more rounded microcapsules. According to Jelvehgari et al. (2004), the higher the concentration of $\mathrm{Ca}^{2+}$ ions, the more crosslinking with sodium alginatepectin occurred resulting in a compact and sturdy structure. Increase in pectin concentration resulted in an oval and relatively large size capsules. Natural structure of pectin which contained neutral sugars such as xylose, galactose and arabinose contribute to the elongation of the capsule (Jaya et al., 2010).

\section{Antioxidant Activity (\%)}

Higher antioxidant activity can be maintained at higher sodium alginate concentration. According to Siswanti et al. (2013), higher concentration of sodium alginate formed tighter and greater pore density which will cause 
the trapped core material trapped becomes increasingly restrained (Figure 11).

The interaction between the ratio of sodium alginate to pectin and $\mathrm{CaCl}_{2}$ concentration showed significant effect on the antioxidant activity of crude folic acid extract microcapsules. The increasing concentrations of $\mathrm{Ca}^{2+}$ made the microcapsules became more cohesive and thus the antioxidant activity could be maintained. According to Seixas et al. (2013), $\mathrm{Ca}^{2+}$ ions could induce crosslinking, thus high concentration of $\mathrm{Ca}^{2+}$ made the bonds between molecules to be more cohesive. The antioxidant activity at $0.05 \mathrm{M} \mathrm{CaCl}_{2}$ increased up to $0.5 \mathrm{M}$ at all sodium alginatepectin ratio, except at $0.1 \mathrm{M} \mathrm{CaCl}_{2}$. At $0.1 \mathrm{M} \mathrm{CaCl}_{2}$, the antioxidant activity increased up to sodium alginatepectin ratio of $70 \%$ : $30 \%$ which then decreased when the sodium alginate concentration increased to $75 \%$. This could be due to the entangled $\mathrm{Ca}^{++}$in the microencapsulate was excessive so that $\mathrm{Ca}^{++}$addition did not increase $\mathrm{Ca}^{++}$ in the texture. This is in line with the study performed by Madziva et al. (2005). The author stated that the best folic acid encapsulation was at alginate to pectin ratio of $70 \%: 30 \%$ and $\mathrm{CaCl}_{2}$ concentration of $0.1 \mathrm{M}$. At $0.1 \mathrm{M}$ $\mathrm{CaCl}_{2}$ it began to weaken, and the weakest was observed at $\mathrm{CaCl}_{2}$ concentration of $0.05 \mathrm{M}$. According to Sari et al. (2004), the amount of $\mathrm{Ca}^{2+}$ absorbed in the network will reach maximum, then increasing the concentration will not increase the amount of $\mathrm{Ca}^{2+}$ into the texture.

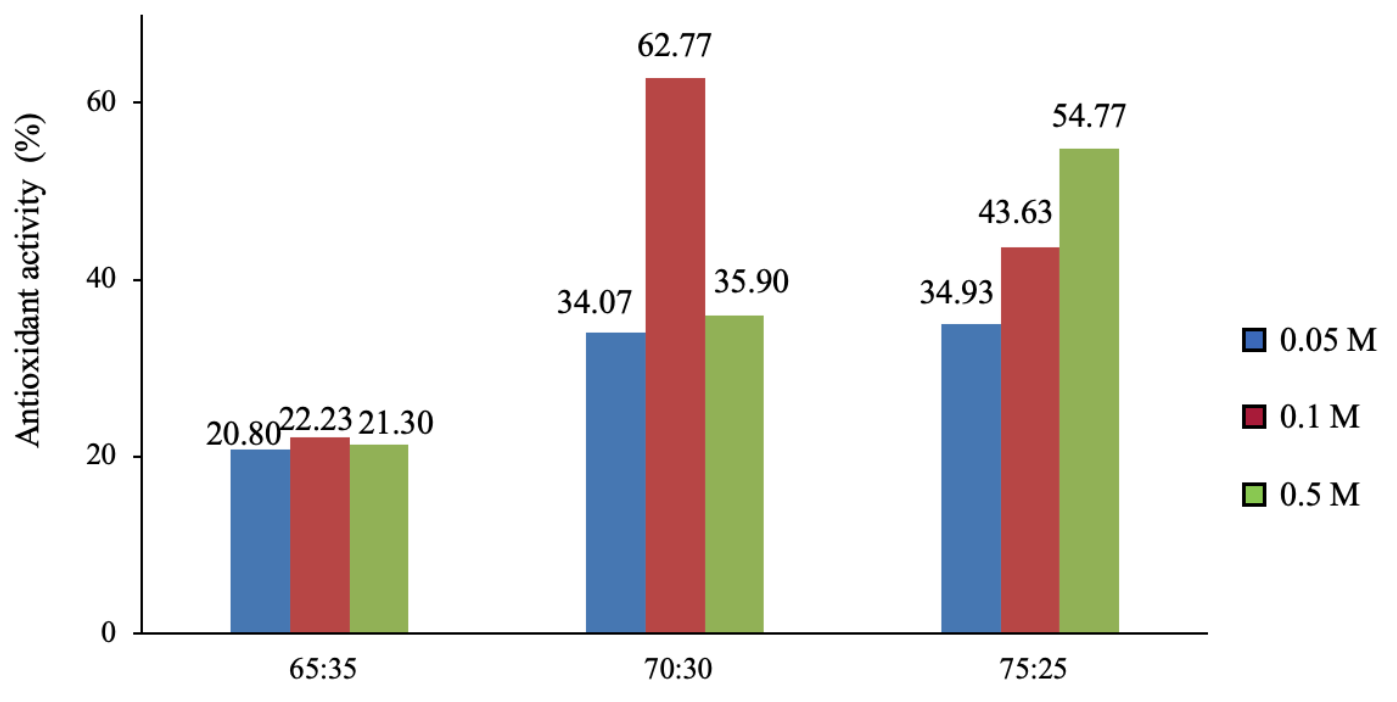

Ratio of sodium alginate with pectin (\%)

Figure 11. The effect of sodium alginate-pectin ratio and $\mathrm{CaCl}_{2}$ concentration on antioxidant activity

(\%) of crude folic acid extract microcapsules

\section{Folic Acid}

Folic acid is an antioxidant compound. Agood Microcapsule is capable of maintaining a network of folic acid so it has the best antioxidant activity such as in the treatment of alginate ratio of $70 \%$ and $30 \%$ pectin with a $\mathrm{CaCl}_{2}$ concentration of 0.1 M. According to Joshi et al. (2001), folic acid is called as a potential antioxidant because of its nature that counteract and neutralize free radicals. The content of folic acid before and after storage at room temperature $\left(28^{\circ} \mathrm{C}\right)$ for one week $(\mathrm{mg} / \mathrm{kg})$ can be seen in Table 1 .

Table 1. Folic acid content before and after storage at room temperature for one week $(\mathrm{mg} / \mathrm{kg})$

\begin{tabular}{lccc}
\hline \multirow{2}{*}{ Folic acid content } & \multicolumn{3}{c}{$\mathrm{A}_{2} \mathrm{M}_{2}$} \\
\cline { 2 - 4 } & $\mathrm{A}_{2} \mathrm{M}_{2(1)}$ & $\mathrm{A}_{2} \mathrm{M}_{2(2)}$ & $\mathrm{A}_{2} \mathrm{M}_{2(3)}$ \\
\hline Before storage & $\mathrm{ND}$ & 3.18 & 2.93 \\
After storage & $\mathrm{ND}$ & 2.83 & 1.95 \\
\hline
\end{tabular}

Note: $\mathrm{ND}=$ Not Detected

$\mathrm{A}_{2} \mathrm{M}_{2}=$ Ratio of sodium alginate :pectin $70 \%: 30 \%$ with $\mathrm{CaCl}_{2}^{2} 0.1 \mathrm{M}$ concentration

The microcapsules of crude folic acid extract stored at room temperature decreased drastically. It is preferable to store the the micocapsules at refrigerator temperature to maintain a micro-encapsulated folic acid extract. According to Onayanti (2015), the viability of the core material which encapsulated by the method of cross-linking produced microcapsules with viability as high as the storage period of 6 weeks at refrigerator temperature $\left(4^{\circ} \mathrm{C}\right)$; while at room temperature $\left(28^{\circ} \mathrm{C}\right)$ the viability was only 1 week.

\section{CONCLUSION}

The best folic acid content found in $\mathrm{A}_{2} \mathrm{M}_{2}$ treatment i.e. microcapsule with alginate to pectin ratio of $70 \%: 30 \%$ $\left(\mathrm{A}_{2}\right)$ and $\mathrm{CaCl}_{2}$ concentration of $0.1 \mathrm{M}\left(\mathrm{M}_{2}\right)$. It had $7.17 \%$ and $8.51 \%$ of crude fiber at alginate to pectin ratio of $70 \%: 30 \%$ and $\mathrm{CaCl}_{2}$ concentration of $0.1 \mathrm{M}$, respectively. Furthermore, the microcapsules water content was found to be $8.51 \%$ and $7.25 \%$ at alginate to pectin ratio of $70 \%$ : $30 \%$ and $\mathrm{CaCl}_{2}$ concentration of $0.1 \mathrm{M}$, respectively, with $5.16 \%$ acidity level; $35.00^{\circ}$ Brix total soluble solid; 416.67 $\mu \mathrm{m}$ diameter; and $62.77 \%$ antioxidant activity. Storage of crude folic acid extract microcapsules was suggested to be at cold temperatures $\left(4^{\circ} \mathrm{C}\right)$ to avoid damage, folic acid content after storage for one week at room temperature decreased significantly, from $3.06 \mathrm{mg} / \mathrm{kg}$ to $2.39 \mathrm{mg} / \mathrm{kg}$. 


\section{REFERENCES}

Abror, M. U. S., and Cahyaningrum, S. E. 2015. Pengaruh konsentrasi agen pengikat silang terhadap karakteristik pirasinamid terenkapsulasi. UNESA Journal of Chemistry. 4(1).

Angraini, A. D. 2006. "Potensi propolis lebah madu Trigona sp. sebagai bahan antibakteri”. Skripsi. Program Studi Biokimia, Bogor.

Aslan, L.M. 1999. "Budidaya rumput laut”. Penerbit Kanisius, Yogyakarta. BPS. 2014. "Produksi Buah-Buahan Menurut Jenis Tanaman 2009-2014". http:sumut.bps.go.id [9 Desember 2015].

Bender, D. A. 2002. "Introduction to nutrition and metabolism, Third edition". New York. Taylor Francis: 380-384.

Dwijayanti, R. 2009. "Pemanfaatan natrium alginat sebagai fortifikasi serat dalam pembuatan minuman serbuk effervescent bercitarasa jeruklemon". Program Studi Teknologi Hasil Perikanan, Institut Pertanian Bogor, Bogor.

Dwiyitno. 2011. Rumput laut sebagai sumber serat pangan potensial. Squalen. 6 (1): 9-17.

Estiasih, T. and Ahmadi. 2009. "Teknologi pengolahan pangan”. Bumi Aksara, Jakarta.

Faradiba., Hasyim, N. and Zahriati. 2013. Formulasi garanul effervescent ekstrak etanol daun jambu biji (Psidium guajava LINN). Majalah Farmasi dan Farmakologi. 12(12).

Fardiaz, D. 1989. Hidrokoloid. Laboratorium Kimia dan Biokimia Pangan. Antar Universitas Pangan dan Gizi. Institut Pertanian Bogor, Bogor.

Febriyenti., Ben, E. S. and Prima, T. 2013. Formulasi mikrokapsul glikuidon menggunakan penyalut etil selulosa dengan metode emulsifikasi penguapan pelarut. Prosiding Seminar Nasional Perkembangan Terkini Sains Farmasi dan Klinik III. ISSN : 23392592.

Fennema, O. R. 1976. "Principles of food sciences". pp.792 Marcel Dekker, Inc. New York.

Fitriani, N. L. C., Walanda, D. K. and Rahman, N. 2013. Penentuan kadar kalium (K) dan kalsium (Ca) dalam labu siam (Sechium edule) serta pengaruh tempat tumbuhnya. Journal Akad. Kim. 1(4): 174-180.

Gusdinar, T., Singgih, M., Priatni, S., Sukmawati, A. E. and Suciati, T. 2011. Enkapsulasi dan stabilitas pigmen karotenoid dari Neurospora intermedia N-1. Jurnal Manusia Dan Lingkungan. 18 (3): 206-211.

Harbone, J. B. 1988. "The flavonoids, advances in research since 1980". Chapman and Hall, New York.

Jaya, S., Durance, T. D., and Wang, R. 2010. Physical characterization of drug loaded microcapsules and controlled in vitro release study. The Open Biomaterial Journal. 2:9-17.

Jelvehgari, M., Mobaraki, V. and Montazam, S. H. 2014. Preparation and evaluation of mucoadhesive beads/discs of alginate and alginopectinate of piroxicam for colon-specific drug delivery via oral route. Jundishapur Journal Nat Pharm Prod. 9(4):1-10.

Joshi, R., Adhikari, S., Patro, B. S., Chattopadhyay, S. and Mukherjee, T. 2001. Free radical scavenging behavior of folic acid: evidence for possible antioxidant activity. Elsivier. Free Radical Biology and Medicine. 30(12):1390-1399.

Juwita, W., Rusmarilin, H. and Yusraini, E. 2014. Pengaruh konsentrasi pektin dan karagenan terhadap mutu permen jely jahe. Jurnal Rekayasa Pangan dan Pertanian. 2(2):42-50.

Lankapalli, S. and Kolapalli, V. 2009. Polyelectrolyte complexes : a review of their applicability in drug delivery technology. Indian Journal Pharmaceutical Science. 7(5): 481-487.
Madziva, H., Kailasapathy, K. and Phillips, M. 2005. Alginate-pectin microcapsules as a potential for folic acid delivery in foods. Journal Microencapsulation 22(4):343-357.

Marliana, S. D., Suryanti, V. and Suyono. 2005. Skrining fitokimia dan analisis kromatografi lapis tipis komponen kimia buah labu siam (Sechium edule Jacq. Swartz.) dalam ekstrak etanol. Biofarmasi. 3(1): 26-31.

Melodita, R. 2011. "Identifikasi pendahuluan senyawa fitokimia dan uji aktivitas antioksidan ekstrak daun cincau hitam dengan perlakuan jenis pelarut". Skripsi. Fakultas Teknologi Pertanian. Universitas Brawijaya, Malang.

Onayanti, N., R. G. Budji. and Sartini. 2015. "Uji viabilitas probiotik asal saluran pencernaan itik pedaging Anas domesticus yang dienkapsulasi dengan metode cross link". Fakultas Matematika dan Ilmu Pengetahuan Alam, Universitas Hasanuddin, Makassar.

Peranginangin, R., A. M. Handayani, D. Fransiska, W. M. Djagal and Supriyadi. 2015. Pengaruh $\mathrm{CaCl}_{2}$ dan alginat terhadap karakteristik analog bulir jeruk dari alginat. Ilmu dan teknologi pangan. JPB Kelautan dan Perikanan. 10(2) : 163-172.

Sani, R. N., Nisa, F. C., Andriani, R. D. and Maligan, J. M. 2014. Analisis rendemen dan skrining fitokimia ekstrak etanol mikroalga laut Tetraselmis chuii. Jurnal Pangan dan Agroindustri. 2(2) : 121-126.

Sari, F. E., Trisnowati, S. and Mitrowiharjo, S. 2004. Pengaruh kadar $\mathrm{CaCl}_{2}$ dan lama perendaman terhadap umur simpan dan pematangan buah mangga arumanis. Fakultas Pertanian. Universitas Gadjah Mada. Ilmu Pertanian. 11(1): 42-50.

Sari, Ratna., Puspita, D. and Rijal, M. A. S. 2012. Pengaruh perbandingan obat polimer terhadap karakteristik fisik dan pelepasan mikropartikel ketoprofen-kitosan. Pharma Scientia. 1(2).

Seixas, F. L., Turbiani, F. R. B., Salomao, P. G., Souza, R. P. and Gimenes, M. L. 2013. Biofilms composed of alginate and pectin: effect of concentration of crosslinker and plasticizer agents. Chemical Engineering Transactions. 32:1693-1698.

Siswanti, C. A., Roosdiana, A. and Sutrisno. 2013. Optimasi amobilisasi pektinase dari Bacillus subtilis menggunakan ca-alginat-kitosan. Kimia Student Journal. 1(2):194-200.

Syahron, Y. N. 2016. "Enkapsulasi ibuprofen dengan natriumn alginatpektin menggunakan metode gelasi ionik". Skripsi. Fakultas Matematika Dan Ilmu Pengetahuan Alam, Institut Pertanian Bogor.

Tan, L. H., Chan, L. W. and Heng, P. W. S. 2009. Alginate/starch composites as wall material to achieve microencapsulation with high oil loading. Informa Heath Care Journal of Microencapsulation. 26(3):263-271.

Tello, F., Cortes, R. N. F., Bustos, F. M., da Silva, V. M., Hubinger, M. D. and Grosso. C. 2015. Alginate and pectin-based particles coated with globular proteins: production, characterization and anti-oxidative properties. Elsivier. Food Hydrocoloids. 43:670-678.

U.S. Department of Agriculture (USDA), Agricultural Research Service. 2008. National Nutrient Database for Standard Reference, Release 21.

Winarno, F. G. 2008. "Kimia pangan dan gizi". M. Brio Press, Bogor

Yuniati, H. and Almasyhuri. 2002. Kandungan vitamin B6, B9, B12 dan E beberapa jenis daging, telur, ikan dan udang laut di bogor dan sekitarnya. Penel Gizi Makan. $\quad 35(1)$ : 78-89. 